\title{
FEDERAL REMOVAL PRACTICE: UTILIZATION OF SECTION I44I(c) BY DEFENDANT PETITIONING ALONE WHERE ALL DEFENDANTS REMOVABLE
}

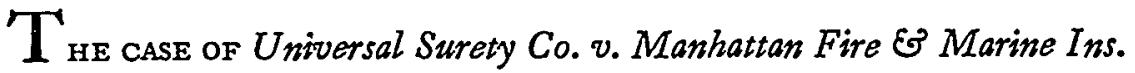

Co., ${ }^{1}$ while reaching a correct result, has drawn attention to what may be an undesirable gap in the federal removal statute. ${ }^{2}$ There, the federal district court remanded a case to the state court on the ground that the defendant, seeking to maintain removal under section $144 \mathrm{I}(\mathrm{c})$ of the Judicial Code, had failed to establish the required "separate and independent claim or cause of action."3 The court went on, however, to

${ }^{1} 157$ F. Supp. 606 (S.D.S.D. 1958). Plaintiff, a Nebraska citizen, was surety on a building contract, and had reconstructed a partially completed building following its destruction by fire. Plaintiff sued in a South Dakota state court both the defendant insurance company, a citizen of New York, on a fire insurance policy taken out by the original contractor, and the building owner, a citizen of Iowa, for breach for an agreement between the owner and the contractor, whereby the owner was to carry insurance on the building during its construction. Both defendants refused to pay for the damage. The defendant insurance company removed to the federal district court without being joined in the petition by the defendant building owner.

228 U.S.C. \& 144 I (1952): "Actions removable generally.

"(a) Except as otherwise expressly provided by Act of Congress, any civil action brought in a State court of which the district courts of the United States have original jurisdiction, may be renoved by the defendant or the defendants, to the district court of the United States for the district and division embracing the place where such action is pending.

"(b) Any civil action of which the district courts have original jurisdiction founded on a claim or right arising under the Constitution, treaties or laws of the United States shall be removable without regard to the citizenship or residence of the parties. Any other such action shall be removable only if none of the parties in interest properly. joined and served as defendants is a citizen of the State in which such action is brought.

"(c) Whenever a separate and independent claim or cause of action, which would be removable if sued upon alone, is joined with one or more otherwise non-removablo claims- or causes of action, the entire case nay be removed and the district court may determine all issues therein, or, in its discretion, may remand all matters not otherwise within its original jurisdiction." -

See the precise wording of 28 U.S.C. \& 1441 (c) (1952), note 2 supra. The present statute was aimed at eliminating some of the confusion surrounding the term "separable controveray"- with the incidental purpose of somewhat restricting federal removal jurisdiction. Historical \& Revision Notes, 28 U.S.C.A. $\$$ 144I (1950). The interpretation given the clause "separate and independent claim or cause of action" by the Supremo Court in American Fire \& Casualty Co. v. Finn, 34x U.S. 6 (x95x), has gone far toward restricting removal under $\$ 144 t$ (c). There the court laid down as the teat 
declare that even had this requirement been met, removal would still have been improper, since the defendant, petitioning alone under section I $44 \mathrm{I}$ (c), had been joined originally in the state court by a codefendant with a removable rather than a nonremovable claim. ${ }^{4}$

Under the provisions of the earlier removal statute, ${ }^{5}$ if a "separable

for "separate and independent" whether there was a single wrong to the plaintiff arising from an interlocked series of transactions. This test might be more accurately stated as being that there are no separate and independent causes of action where there is a wrongful invasion of a single right. The language comes from Baltimore S.S. Co. v. Phillips, 274 U.S. 316,321 (1927) quoted in American Fire \& Casualty Co. v. Finn, supra at 133 , as follows:

"Upon principle, it is perfectly plain that the respondent suffered but one actionable wrong and was entitled to but one recovery, whether his injury was due to one or the other of several distinct acts of alleged negligence or to a combination of some or all of them. In either view, there would be but a single wrongful invasion of a single primary right of the plaintiff, namely, the right of bodily safety, whether the acts constituting such invasion were one or many, simple or complex."

It is interesting to note that the language in the Phillips case meant only that different allegations of negligence made against one defendant constituted only one cause of action. There can be no doubt that the Finn case extends the quoted language to cover actions against two defendants severally. "The single wrong for which relief is sought is the failure to pay compensation for the loss of the property. Liability lay annong the three parties, but it was uncertain which was responsible." American Fire \& Casualty Co. v. Finn, supra at 14. And in Mayflower Industries v. Thor Corp., 184 F.2d 537 (3rd Cir. 1950) no "separate and independent claim" was found because there was only a "single economic injury."

In light of the statutory history and the holding in the Finn case, the determination in the instant decision that there was no "separate and independent claim or cause of action" seems clearly correct. As to the restrictive effect of the Finn test see 40 CAIIF. L. REv. 317 (1952); 52 Colum. L. REv. 101 (1952); 46 ILL. L. REV. 335 (I95I); 49 Mich. L. REv. 1236 (195I). And for a caustic criticism of the Finn decision and its probable effect see Keefe, Venue and Removal Jokers in the New Federal Judicial Code, 38 VA. L. REv. 569 (1952).

A case decidedly similar on the facts to the instant case, but in which "separate and indepndent" causes of action were found is Conmander-Larabee Milling Co. v. JonesHettelsater Constr. Co., 88 F. Supp. 476 (D.C. Mo. 1950), decided prior to the Finn case.

I57 F. Supp. at 610. See also the language of 28 U.S.C. $\$ 144$ I (c) (1952), note 2 supra.

8 36 Stat. rog4 (1932), as amended 28 U.S.C. \$ 71 (1940). The third sentence of the former statute provided: "And when in any suit mentioned in this section there shall be a controversy which is. wholly between citizems of different States, and which can be fully determined as between them, then either one or more of the defendants actually interested in such controversy may remove said suit into the district court of the United States for the proper district."

The evolution of $\$$ r $44 \mathrm{I}$ (c) of the 1948 .revision from former $\$ 7.1$ of the Judicial Code, has been the subject of much legal writing. See American Fire \& Casualty Co. v. Finn, $34 x$ U.S. 6 (1950), noted in 40 Calip. L. RET. 327 (1952) 53 Colux. L. 
controversy" were removable, the entire case could be removed. ${ }^{\circ}$ It seems apparent from a reading of newer section $\mathrm{I} 44 \mathrm{I}$ (c) that in revising the old statute, the intention had been to preserve this feature of removal practice. ${ }^{7}$ However, the insertion of the limitational words, "whenever ... joined with one or more non-removable claims or causes of action" would seem specifically to preclude removal under section I44I(c) by a party or parties defendant ${ }^{8}$ to a removable claim when such claim is

REv. IOI (I952); 46 IlL. L. REv. 335 (I95I); 49 MICH. L. REv. 1236 (1951); 25 So. CAL. L. Rev. 379 (1952); Annot., I9 A.L.R.2d 748 (1951); Lewin, The Federal Courts' Hospitable Back Door-Removal of Separate and Independent Non-Federal Causes of Action, 66 HARV. L. REv. 423 (1953); Comment, 33 CoRNell L.Q. 261 (1947); Note, 33 MiNN. L. REv. 738 (I949). The "separable controversy" test of former $\S 7$ I gave rise to much litigation and confusion as to what constituted such a "separable controversy." Probably the most authoritative view was that adopted by Professor Moore. The essence of his position is that a "separable controversy" exists only where liability is several or alternative among the defendants, such as would allow a permissive joinder under the Federal Rules of Civil Procedure, but not where joint liability is alleged, in which case the defendants would be indispensable parties. MOORE, Commentary on The United States Judicial Code, 242-48 (1949).

- City of Gaimesville v. Brown-Crummer Investment Co., 277 U.S. 54 (1928) reversing 20 F.2d 497 (5th Cir. 1927); Barney v. Latham, 103 U.S. 205 (1880); Texas Employers Ins. Ass'n v. Felt, I50 F.2d 227 (5th Cir. 1945). But that partial remand might be made where the controversy was "separate" rather than "separable," see Curacao Trading Co. v. Federal Ins. Co., 40 F. Supp. 846 (S.D.N.Y. 1941). But cf., Eber Bros. Wine \& Liquor Corp. v. Firemen's Ins. Co., 29 F. Supp. 772 (S.D.N.Y. 1 939).

Prior to 1866 there was no removal without complete diversity regardless of whether or not the suit contained separate or separable controversies or causes of action. From I 866 to 1875 the suit was split into two parts where such a separable controversy existed, one part left in the state court and the other removed to the federal court. The disadvantages of having a part of the suit in a state court and part in a federal court caused a change in 1875 to the effect that the entire suit was removed to the federal court if a separable controversy existed which could be removed.' Barney v. Latham, supra. On September I, 1948, \$ 144 I (c) became effective changing the standard from "separable controversy" to "separate and independent claim "or cause or action" and also providing for discretionary remand of the nonremovable separate causes of action. 'For a sum* mary of the previous acts and their historic background see Texas Employers Ins. Ass'n v. Felt, supra.

- "However, the last clause of $\$ 144 \mathrm{r}(\mathrm{c})$. expressly" piovides for discretionary rcmand of nonremovable inatter. See note 2 supra. This provision has been severely criticizzed: Keefe, Venue ard Removal Jokers in the New :Federal Judicial Code, 38 VA: L. 'REv. 569, 611 (1952); Note, 33 CoRnell-L.Q. 26ij 270 (194h):

: 28 U.S.C.: $\$ 144 \mathrm{r}^{\circ}(\mathrm{c})$ ( $\left.1952^{\circ}\right)$ has" beeñ the separate cause of action to join in petitioning; thus varying from the language, "ohe or more defendants actually-interested " $_{3}$ "employed in the former provision: 'Colorado' ex rel. Land Acquisition Comm'n v. American Machine-\& Foundry 'Co.; i $43^{\prime}$ F. Supp:

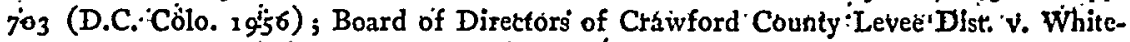
side, $87 \cdot$ F..Supp. $6 \dot{9}$. (W.D. Airk 1949)..." 
joined only with another removable claim, as in the present case. ${ }^{9}$ of course, section I44I (a) provides an avenue for removal of such claims by the "defendant or defendants," under which the courts have required joinder of all defendants in the removal petition, ${ }^{10}$ but there is no comparable provision in section I44I(c). The result, if I44I (c) be read as an exception to $144 \mathrm{I}$ (a) with regard to the requirements of unanimity among the defendants, is anomalous. A claim which originally would not lie within federal jurisdiction may be removed from a state to a federal forum, irrespective of the wishes of the defendant to that claim; $;^{11}$ while a claim which could have been brought in the federal courts in the first instance cannot be removed from a state court by a single defendant, but requires the joinder of all other removable defendants in the petition for removal, at least where no nonremovable claim is present.

Assuming, for purposes of illustration, that a separate and independent claim did exist in the Universal Surety Co. case, three views of the removal statute, especially section I44I (c), seem possible.

First, it may well be that the result which the court predicted by way of obiter dictum would be a desirable one. Since both defendants might have removed under section I44I (a) by joining in the removal petition, the case would differ from that in which a defendant lacking diversity is made a party, often for the very purpose of preventing removal. ${ }^{12}$ It is felt that the latter situation is what $144 \mathrm{I}$ (c) was specifically designed to cover. Yet, in the instant situation had either de-

\footnotetext{
${ }^{\circ}$ This would seem to follow by negative implication or perhaps from the maxim expressio unius exclusio alterius. That is, Congress by providing for removal where joined with a nonremovable claim, implies that the section should not apply where joined solely with a removable claim.

. ${ }^{10}$ Chicago, Rock Island \& Pacific Ry, v. Martin, 178 U.S. 245 (1900); Wright v. Missouri Pac. R.R., 98 F.2d 34 (8th Cir. 1938); Gratz v. Murchison, 130 F. Supp. 709 (D.C. Del. 19.55); Barnes v. Parker, 126 F. Supp. 649 (W.D. Mo. 1954); Warner v. Dunmyer, 108 F. Supp. 757 (W.D. Mo. I952); Smith v. Waldemar, 85 F. Supp. 36 (E.D., Tenri. 1949):

${ }^{11}$ This would be the case where a non-resident defendant removed on the basis of $\S \mathrm{r} 44 \mathrm{x}$ (c) taking with him a resident defendant who was not diverse as to the plaintiff. There is some controversy as to the constitutionality of this provision. That the current, removal statute exceeds the constitutional grant of jurisdiction see Lewin, The Federal, Courts' Hospitable Back Door-Removal of. Separate and Independent Non-Federal

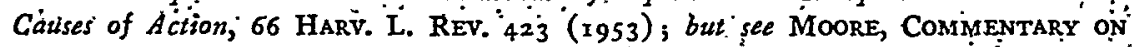
the United States Jupicial Code 253 (1949).

$\therefore{ }^{22}$ For"an" extreme example of this practice see Pulliman Co. v. Jenkins, 305 U.S. 534 (igj8), discussed in Móoke; CoMMENTARY ON THE UNITED STATES JUDICIAL CODE $2 \ddot{4} 6 \cdot(1949) \div$
} 
fendant been sued alone, he would then have had the choice of defending in the state court or removing to the federal court. Allowing the codefendant with a removable claim to keep the entire case in the state court by refusing to join in the petition for removal ${ }^{13}$ would harmonize with the current trend to contract removal jurisdiction, ${ }^{14}$ and this result may not seem unjust when it is considered that two of the parties prevail in their choice of forum, defeating the efforts of the third toward effecting removal. The argument loses much of its merit, however, if a situation is imagined wherein there are a large number of defendants, each with a removable claim, only one of whom desires to remain in the state court. In that event, sheer weight of numbers would seem to dictate a contrary result. Furthermore, it would seem undesirable to leave a defendant's removal chances under the "separate and independent claim" provisions of section $\mathrm{r} 44 \mathrm{r}(\mathrm{c})$ to the vagaries of state joinder procedures, some of which, by virtue of their liberal terms, would permit a plaintiff to join a removable defendant who he knew in advance would not consent to removal.

Another possible interpretation, apparently discarded by the court in the present case, would have allowed removal, assuming, again, that a separate and independent cause of action existed. This construction would require reading "whenever . . . is joined ..." as meaning "even if . . . joined with one or more otherwise non-removable claims or causes of action."15 Reading the statute in this manner, it could reasonably be inferred that the provision contained the implication that a removable defendant could, on his own petition, remove the claim in all cases where he was joined only with another removable defendant, and that the language concerning nonremovable claims was inserted to insure that similar procedure could be followed where a nonremovable party happened to be involved. Such an interpretation requires holding that section $144 \mathrm{r}$ (c) alone governs those rases in which separate and independent claims or causes of action are joined, with the necessary im-

\footnotetext{
"See note 8 sufra.
}

11 American Fire \& Casuatty Co. v. Finn, 347 U.S. 6 (1950); South Carolina Elec. \& Gas Co. v. Aetnz Ins. Co., 114 F. Supp. 79 (E.D.S.D. 1953); Babb v. Paul Revere Lifo Ins. Co., 102. F. Supp. 247 (W.D.S.C. 1952); Cudahy v. Midcontinent Airlines, Inc., 98 F. Supp. 403 (E.D. Mo. 1951) ; I Barkon \& Holtzopp, Frdirent Practice and PRocedure 8101 (Supp. 1957).

${ }^{14}$ See the precise wording of $\$ 144 \mathrm{I}$ (c), note 2 supra. The court in the present case used the langoage "whether joined" in considering this argument, 257 F. Supp. at $6 \times 0$, bue it is felt that this is approximated by the "even if" language employed here. 
plication that subsections (a) and (b) of section I44I have no bearing on such situations.

A final possibility, and perhaps the most accurate interpretation, is that the problem instantly posed is one which Congress did not contemplate. It seems plausible to believe that Congress, in fact, did not advert to the possibility that removal of two removable joined causes of action would be attempted under section I44I(c), since normally one would expect the defendants in such a case to be in agreement on the removal issue and to remove, if at all, under section I44I(a). Significantly, neither the revisors of the statute nor the leading authorities on procedure have mentioned the situation under discussion. ${ }^{16}$

Thus, it is submitted that while the dictum in Universal Surety Co. v. Manhattan Fire E M Marine Ins. Co. may be in conformity both with accepted rules of construction and with the trend of recent cases toward contracting removal jurisdiction, Congress should act to clarify the anomaly lurking in section I44I, with respect to what parties must be joined in petitioning for removal and what circumstances bring a case within the scope of section I44I(c).

\footnotetext{
${ }^{10}$ There is no intimation that such a view was contemplated either in the revisor's notes appended to the statute, 28 U.S.C.A. \$ 144I (1950), unofficially in publications by the men active in the preparation of the revision, Barron, The Judicial Code; 1948 Revision, 8 F.R.D. 439 (1949); Maris, An Introduction to the Nesu Federal Judicial Code: Enactment by 8oth Congress a Notable Gain, 34 A.B.A.J. 863 (1948), nor in the pertinent sections of other authoritative works, MOORE, COMMENTARY ON THE UNITED STATES JUDICIAL CODE $2 \times 5-88$ (1949); I BARRON \& HOLTZOFF, FEDERAI Practice and Procedure $\$ \S$ iol-09 (1950).

One view is expressed that the change in language from "wholly between citizens of different states" to "is joined with one or more otherwise non-removable claims or causes of action" was designed primarily to insure the elimination of any discrimination against citizens of the territories and the District of Columbia, 33 CORNELL L.Q. 26I, $271(1947)$.
} 